Stoker, M. G. P., Smith, K. M. \& Ross, R. W. (1958). J. gen. Microbiol. 19, 244-249

\title{
Electron Microscope Studies of HeLa Cells Infected with Herpes Virus
}

\author{
By M: G. P. STOKER, K. M. SMITH AND R. W. ROSS \\ Department of Pathology, University of Cambridge, and the Agricultural \\ Research Council Virus Research Unit, Cambridge
}

\begin{abstract}
SUMMARY: Monolayer cultures of HeLa cells were exposed to a high multiplicity of herpes virus per cell. Samples of cells taken at successive time intervals after infection were sectioned and examined by electron microscopy for characteristic ringed particles. Replicate cultures of cells were assayed for infective virus. Despite an estimated input of $6 \mathrm{HeLa}$ plaque-forming units (pfu)/cell, an infective centre count indicated that only $6 \%$ of the cells yielded virus. No increase in infective virus was found in the cultures at $9 \mathrm{hr}$. and no characteristic particles were found in sections of 28 cells. At $12 \mathrm{hr}$. new virus appeared in the cell fraction and particles were found in the nuclei of 2 of 25 cells. At $26 \mathrm{hr}$. after infection and later, there was a large increase in virus in both cell fraction and medium, and large numbers of particles were present in the nucleus and cytoplasm and on the cell surface.
\end{abstract}

The electron microscope studies of Morgan, Ellison, Rose \& Moore (1954) on sections of chorioallantoic membrane cells infected with herpes virus have shown particles in the nucleus and cytoplasm of the infected cells. The size of the particles in the cytoplasm agrees with other estimates, and it could be tentatively assumed that they were in fact virus particles. Such particles were round or oval in section and had a characteristic internal structure. The intracellular cytoplasmic particles consisted of a dense central body, surrounded by a double membrane. In the nucleus, however, the particles contained the same central body but only one membrane.

A study of the growth of herpes virus in HeLa cells has shown that formation of a new infective virus is first detectable in the cells at $12 \mathrm{hr}$. after exposure. The virus is not released into the culture medium, however, until $16 \mathrm{hr}$. or more after exposure (Stoker \& Ross, 1958). It has also been found that the cells start to synthesize excess deoxyribosenucleic acid (DNA) 6-9 hr. after infection, before the appearance of infective virus (Newton \& Stoker, 1958). It was, therefore, of interest to examine HeLa cells by electron microscopy during the latent period to see whether virus particles appeared at the time of DNA synthesis but before the rise in infectivity. It was hoped that their fairly large size and characteristic cross-section might make these particles relatively easy to identify amongst the other constituents of nucleus and cytoplasm.

\section{METHODS}

The maintenance of the HeLa cells, the culture media, and certain other experimental details will be described more fully in a separate communication on the growth of herpes virus (Stoker \& Ross, 1958). 
The Melbourne egg- and mouse-adapted variant of the HF strain of herpes virus (HFEM) was used. Seed suspensions were prepared from infected HeLa cell culture media after eight or more passages in these cells. The virus was assayed by pock counts on the chorioallantoic membrane (CAM) because this was more than ten times more sensitive than titration in $\mathrm{HeLa}$ cells, even after passage in these cells. Virus input, however, has been deduced from adsorption data obtained by Farnham (1958), using a plaque-counting method in HeLa cells.

Flat-sided tubes containing monolayers of $10^{5} \mathrm{HeLa}$ cells were exposed to 200 pock-forming units of virus/cell. This is equivalent to $7 \mathrm{HeLa}$ plaqueforming units/cell under the same experimental conditions. After $2 \mathrm{hr}$. the excess virus was removed by washing and treatment with herpes antiserum, and the cells were then incubated at $37^{\circ}$ in medium. Two hours allows adsorption of about $80 \%$ of HeLa infectious virus, so the theoretical input multiplicity was approximately 6 . At 5, 9, 12 and $26 \mathrm{hr}$. the medium was removed from 4 tubes, pooled, and titrated for infective virus. The cells from the tubes were removed from the glass with a $1 / 20,000, w / v$, solution of sodium EDTA (ethylenediaminetetra-acetic acid), pooled, pipetted to break up clumps, and counted in a haemocytometer chamber. The pooled cell suspension was then centrifuged and the supernatant EDTA solution removed for virus assay.

The cell pellet was washed once with buffered saline, redeposited and left in $1 \%(\mathrm{w} / \mathrm{v})$ osmium tetroxide buffered at $\mathrm{pH} 7 \cdot 4$ for $40 \mathrm{~min}$. The fixative was then removed and the cells replaced in buffered saline for not more than $2 \mathrm{hr}$. before embedding. For embedding, a mixture of 8 parts butyl methacrylate to 2 parts methyl methacrylate was used. Sections were cut on a Cook and Perkins ultra-microtome using a glass knife. The electron micrographs were taken on a Siemens Elmiskop I microscope at $60 \mathrm{kV}$. Uninfected HeLa cells, maintained in medium and prepared in the same way, were also fixed for sectioning. During the latent period, at 5 and $9 \mathrm{hr}$., unfixed cells, suitably diluted in medium, were inoculated on to the chorioallantoic membrane of embryonated eggs for an estimation of the proportion of pock producing, i.e. infected, cells.

\section{RESULTS}

The time of appearance of infective virus in the cultures is shown in Fig. 1. Less than $0.01 \%$ of the original inoculum was present in the fluid and EDTA fractions after washing and treating the cells with antiserum. Despite the large input of virus only $5 \times 10^{3}$ cells in each tube yielded virus when inoculated on to chorioallantoic membrane, that is $6 \%$ of the total cells. A rise in infectivity was first detected in the EDTA fraction at $12 \mathrm{hr}$. but there was no appearance of new virus in the medium at this stage. At $26 \mathrm{hr}$. the EDTA fraction and medium showed a considerable rise in infective virus. These results agree closely with more detailed investigations of the growth of virus in HeLa cells which also show that the rise in the EDTA fraction coincides with the increase in infective virus in the disintegrated cells (Stoker \& Ross, unpublished). 


\section{Electron microscopic appearances}

Sections of normal HeLa cells show densely granular material in the nucleus and recognizable nucleoli. A few cells, however, contain rather empty nuclei resembling those in infected cells (see below) but none of the typical ringed particles are seen, and there is no accumulation of the granular material at the nuclear membrane in uninfected cultures.

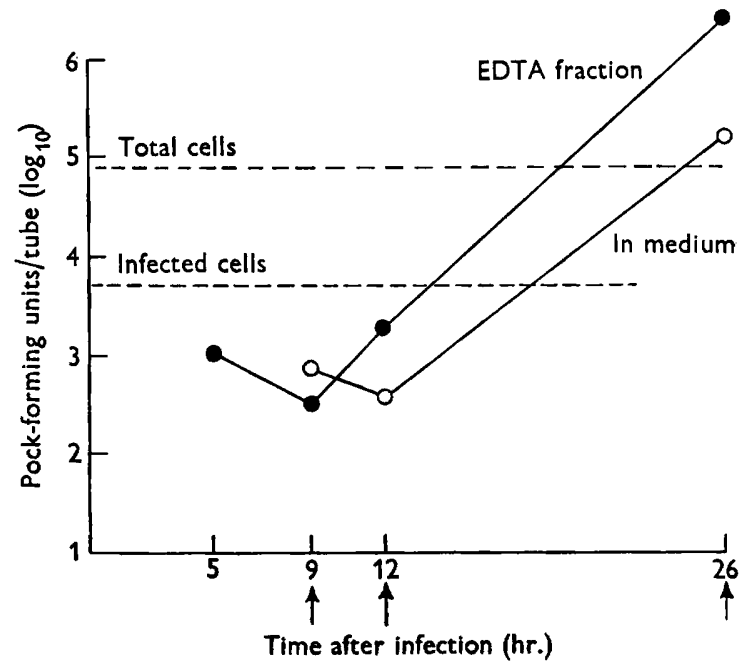

Fig. 1. Development of infective herpes virus in medium and EDTA fraction of HeLa cells inoculated with 6 plaque-forming units/cell. Arrows denote times at which cells were fixed for examination by electron microscopy.

At $9 \mathrm{hr}$. after infection (Pl. 1, fig. 1) no typical ringed particles were seen in cytoplasm or nucleus in sections of 28 cells taken at random. The nuclei were not obviously different from the normal cells, but irregular material, elongated, oval or rounded in section, was present on or near the cell surface. This material did not resemble the ringed particles present later in the infection, and they were taken to be cytoplasmic protrusions.

At $12 \mathrm{hr}$. after infection, examination of sections of 25 cells showed two cells with 9 and 4, respectively, typical ringed particles visible in the nuclei (Pl. 2, figs. 2, 3). These nuclei also showed considerable loss of granular material except at the nuclear margin. Four other cells exhibited loss of nuclear structure without recognizable ringed particles. The remaining cells appeared normal.

At $26 \mathrm{hr}$. after infection many of the nuclei were almost devoid of granular material, and large numbers of typical ringed particles were seen ( $\mathrm{Pl}$. 3, figs. 4, 5; Pl. 4, figs. 6, 7). These were present in the nucleus, in the cytoplasm and on the cell surface. In these, as in the $12 \mathrm{hr}$. cultures, it was not possible to tell what proportion of the cells contained particles, because each cell could not be serially sectioned and examined in all its dimensions.

In a separate experiment carried out in the same general way, cells were 
taken $96 \mathrm{hr}$. after exposure to a low input of virus $(0 \cdot 1$ pock units/cell), when stained preparation showed gross cytopathic change (Ross \& Orlans, 1958). Electron microscopic examination of sections (Pl. 5, fig. 8; Pl. 6, fig. 9; Pl. 7, fig. 10) again showed extensive loss of nuclear structure, and large numbers of ringed particles, mostly in the nuclei and on the cell surface, rather than in the cytoplasm.

\section{General features of infected cells}

In the 26 and in the $96 \mathrm{hr}$. specimens particles in the nucleus showed a central dense granule and single membrane, while those in the cytoplasm and on the cell surface apparently had double membranes. It is possible, however, that this effect might be caused by a thickening of the single membrane, because the gap between the two membranes is itself granular and not so clear as the area between the inner ring and central spot.

The largest diameter of 31 of the extranuclear particles sectioned nearly equatorially through the central body, gave a mean value of $135 \mathrm{~m} \mu$. Particles were sometimes seen with thick or double membranes in the marginal granular material of the nucleus (Pl. 5, fig. 8), but these might have been in cytoplasmic invaginations of the nuclear membrane. An occasional particle with a double ring appeared to be within the nuclear membrane, however ( $\mathrm{Pl}$. 3, fig. 4). Most of the nuclear particles were scattered and only one area was seen which might constitute a colony of developing virus.

Whereas the extranuclear virus at $26 \mathrm{hr}$. was in the cytoplasm, at $96 \mathrm{hr}$. (in a different experiment with a small virus input), it was found largely on the cell surface, or in complicated crypts and invaginations of the cytoplasmic membrane (Pl. 6, fig. 9). Apparently treatment of the cells with EDTA, which removes calcium and magnesium ions, does not release all the virus from the surface of the cells.

\section{DISCUSSION}

To evaluate the electron microscopic changes during virus growth it is desirable to know the stage of infection in each cell examined, or alternatively to examine a population of cells which were all infected simultaneously, with subsequent events in the growth cycle proceeding synchronously. Except with bacteriophage, this ideal has not been achieved. In the examination of HeLa cells infected with herpes virus reported in this paper only $6 \%$ of the initially infected cells were shown to yield virus, by infective centre counts on chorioallantoic membrane. Calculation of virus input suggests that this is a low estimate, similar to that found by Kaplan (1957) with herpes virus in rabbit kidney cells. It is known that new infective virus can be detected in the cells and EDTA fraction at $12 \mathrm{hr}$. but not at $9 \mathrm{hr}$. In the sections characteristic particles were also found first at $12 \mathrm{hr}$. in 2 of 25 cells examined. No particles were found at $9 \mathrm{hr}$., but it would be impossible to examine a large enough number of cells sufficiently completely to exclude the presence of such particles. Nevertheless, it is known that the cells at this stage have synthesized an excess of DNA (Newton \& Stoker, 1958). If herpes virus itself 
contains DNA it would require, even at a conservative estimate, an average of $10^{5}$ to $10^{6}$ particles/cell to account completely for the excess at $9 \mathrm{hr}$. There was certainly no evidence from the electron micrographs at 9 or even $12 \mathrm{hr}$. that this number of particles was present.

We are grateful to Miss S. Vernon Smith and Mr G. J. Hills for the electron microscopy. This work was supported by grants from the Medical Research Council and the Agricultural Research Council.

\section{REFERENCES}

Farnham, A. (1958). The formation of microscopic plaques by herpes simplex virus in HeLa cells. Virology, to be published.

KAPLAN, A. S. (1957). A study of herpes simplex virus-rabbit kidney cell system by the plaque technique. Virology, 4, 435 .

Morgan, C., Ellison, S. A., Rose, H. M. \& Moore, D. H. (1954). Structure and development of viruses as observed in the electron microscope. I. Herpes simplex virus. J. exp. Med. 100, 195.

Newton, A. \& Stoker, M. G. P. (1958). Changes in nucleic acid content of HeLa cells infected with herpes virus. Virology, $5,549$.

Ross, R. W. \& Orlans, E. (1958). The redistribution of nucleic acid and the appearance of specific antigen in HeLa cells infected with herpes virus. J. Path. Bact. 91, 250.

Stoker, M. G. P. \& Ross, R. W. (1958). Quantitative studies on the growth of herpes virus in HeLa cells. J. gen. Microbiol. 19, 250.

\section{EXPLANATION OF PLATES}

\section{Plate 1}

Fig. 1. 9 hr. after infection. Apparently normal HeLa cell. $\times 12,000$.

Plate 2

Fig. 2. $12 \mathrm{hr}$. after infection. Part of nucleus with the first characteristic single ringed particles to be seen. (In this and other plates some of the particles are indicated with arrows.) $\times 65,000$.

Fig. 3. $12 \mathrm{hr}$. after infection. Part of nucleus and cytoplasm of another cell, showing characteristic particles. $\times \mathbf{3 3 , 0 0 0}$.

\section{Plate 3}

Fig. 4. $26 \mathrm{hr}$. after infection. Giant cell showing part of two nuclei. Typical single ringed particles in nucleus and double ringed particles in cytoplasm. One intranuclear particle has a double ring (arrow). $\times 33,750$.

Fig. 5. $26 \mathrm{hr}$. after infection. Part of three nuclei in giant cell with intranuclear, single ringed particles. $\times 31,500$.

Prate 4

Fig. 6. $26 \mathrm{hr}$. after infection. Nucleus and disrupted cytoplasm of cell with characteristic particles. $\times 31,500$.

Fig. 7. $26 \mathrm{hr}$. after infection. Cytoplasmic particles lying inside membranes, possibly invaginations of cell membrane. $\times 31,500$.

\section{Prate 5}

Fig. 8. $96 \mathrm{hr}$. after infection. Characteristic particles in nucleus, cytoplasm and on cell surface. Group of double ringed particles are shown inside the nucleus, possibly in invaginated nuclear membrane. $\times 32,400$. 
Journal of General Microbiology, Vol. 19, No. 2

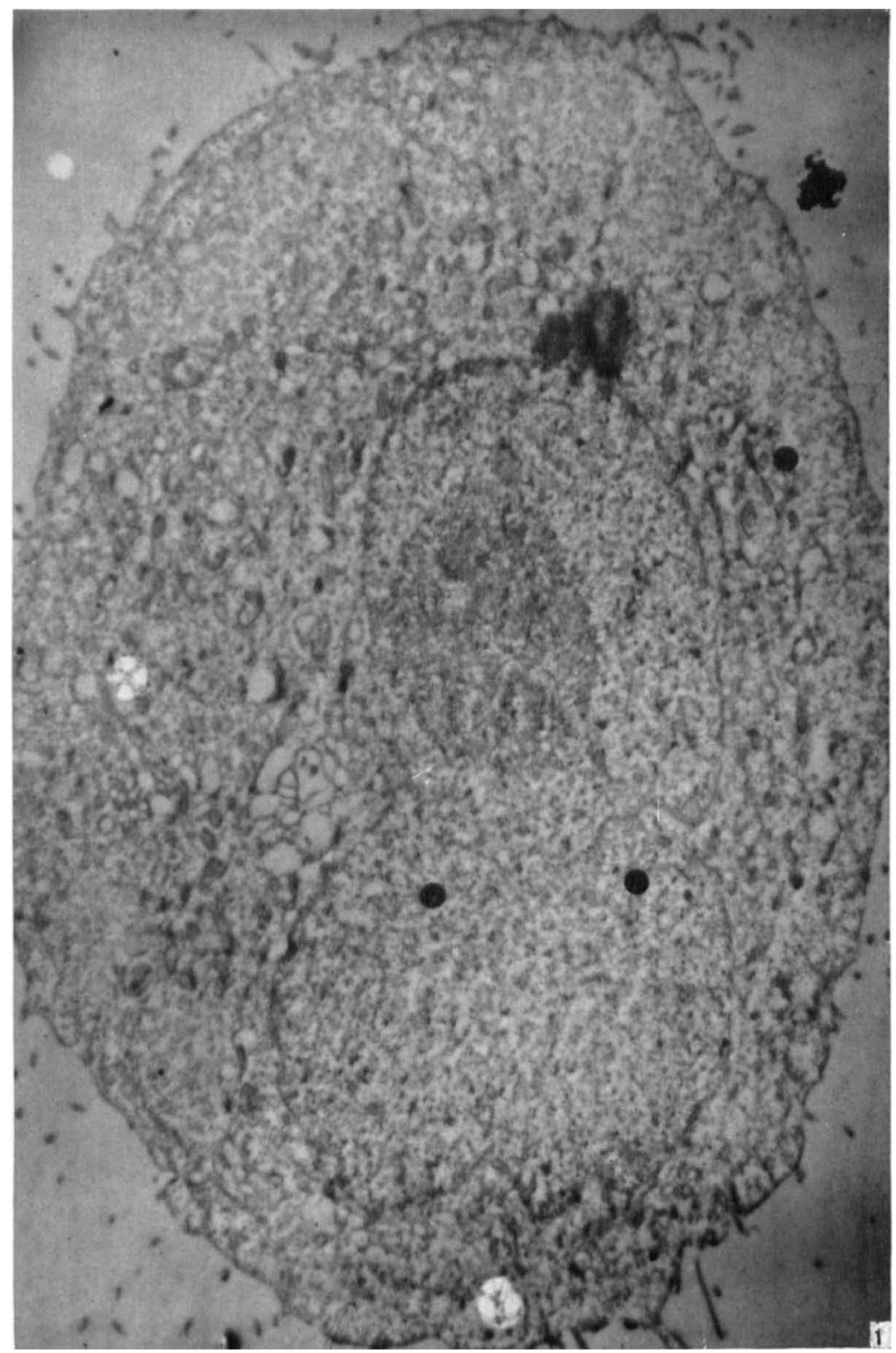

M. G. P. Stoker, K. M. Smith \& R. W. Ross--Electron microscopy of merpes virus. Plate 1 
Journal of General Microbiology, Vol. 19, No. 2
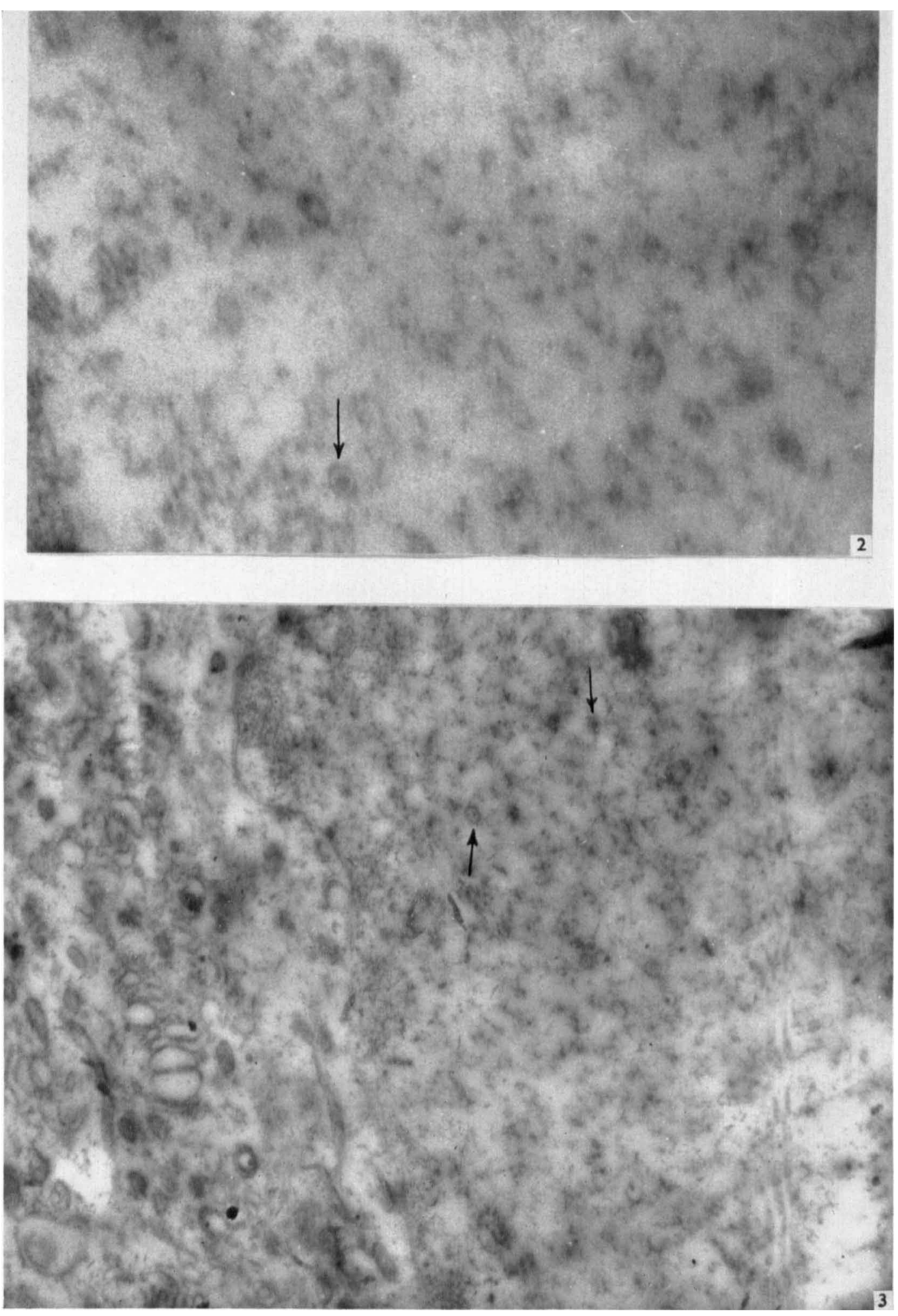

M. G. P. Stoker, K. M. Smith \& R. W. Ross-Electron microscopy of herpes virus. Plate 2 
Journal of General Microbiology, Vol. 19, No. 2
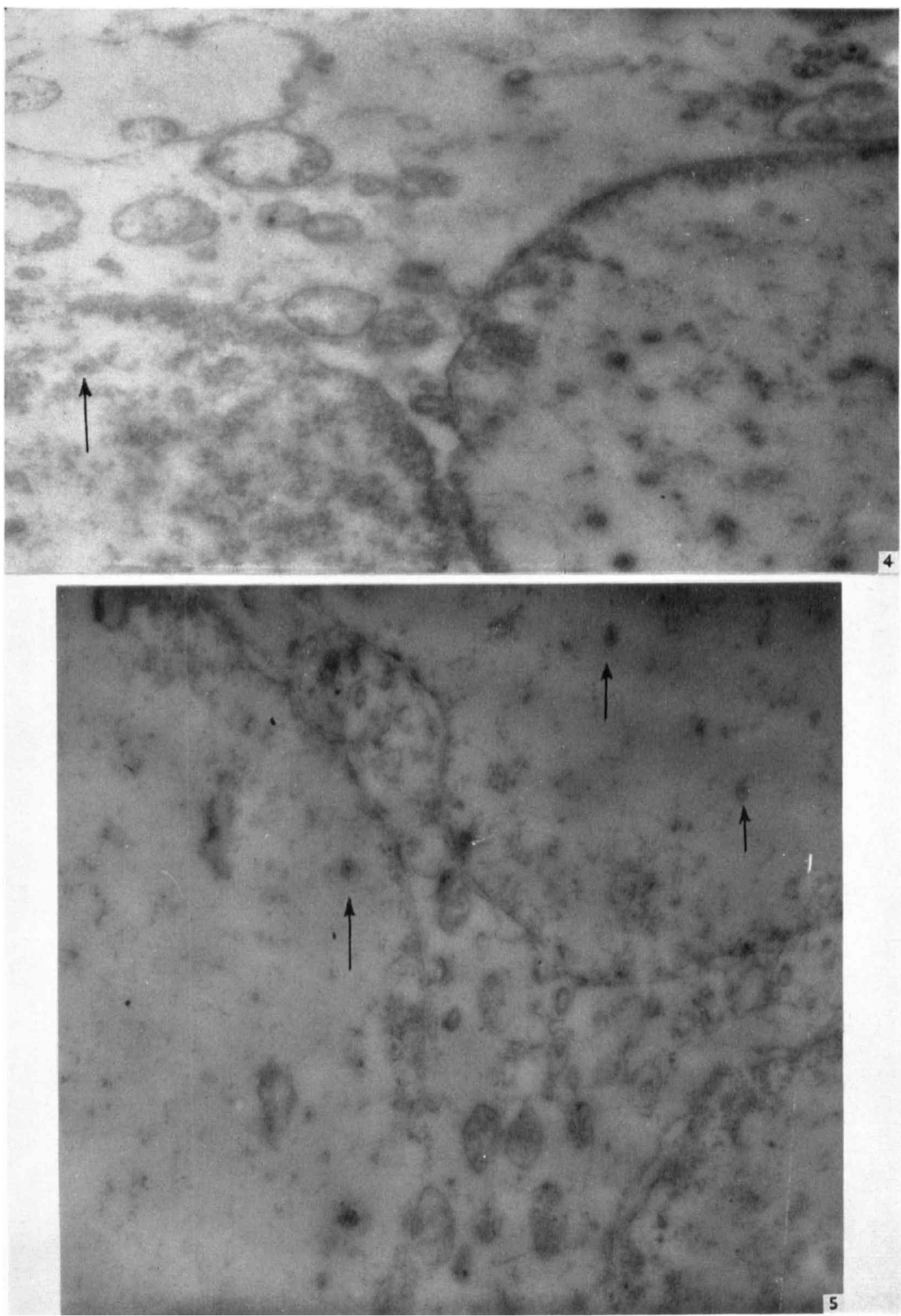

M. G. P. Stoker, K. M. Smith \& R. W. Ross-Electron miscrocopy of herpes virus. Plate 3 
Journal of General Microbiology, Vol. 19, No. 2
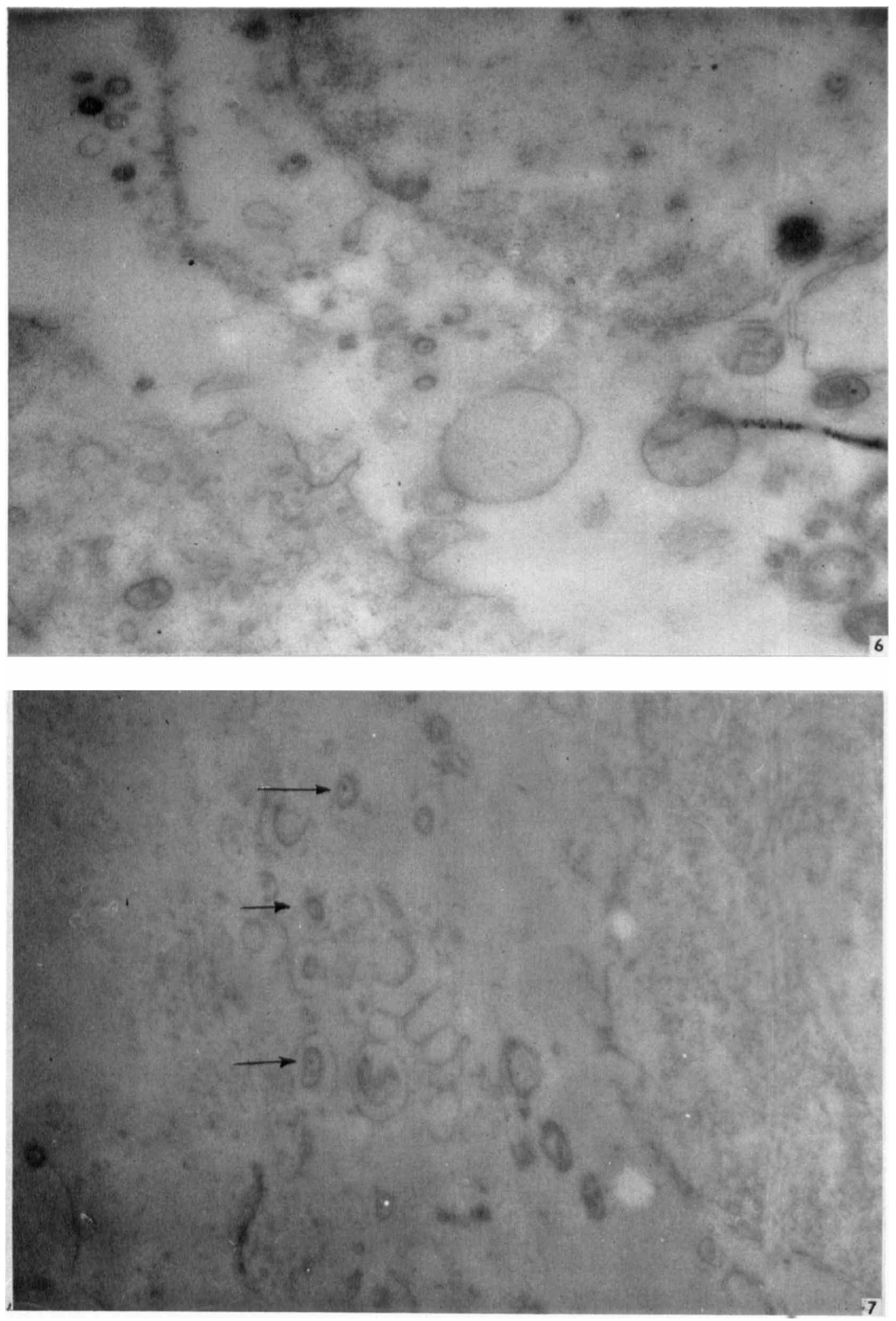

M. G. P. Stoker, K. M. Smith \& R. W. Ross-Electron Microscopy of HeRPeS virus. Plate 4 
Journal of General Microbiology, Vol. 19, No. 2

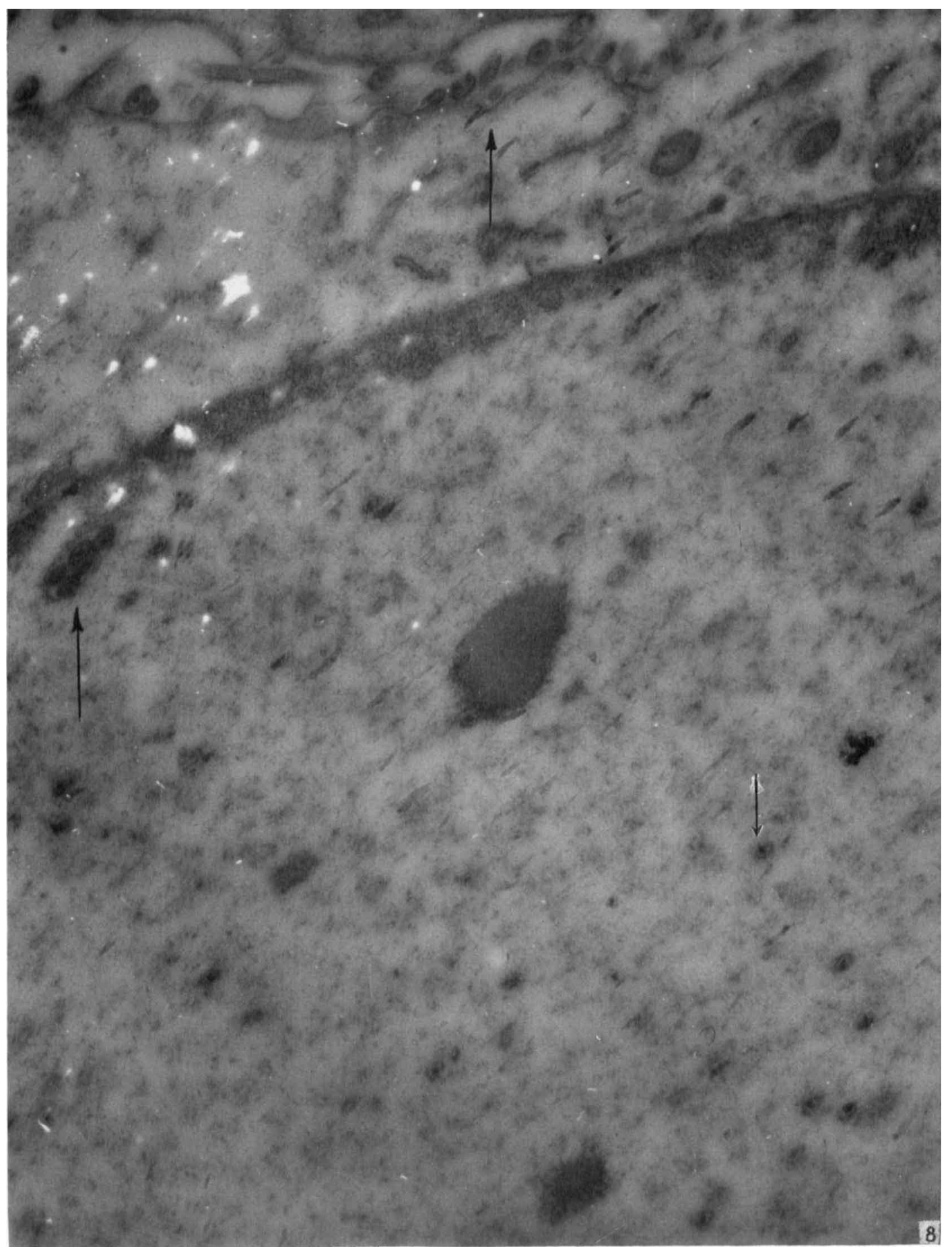

M. G. P. Stoker, K. M. Smith \& R. W. Ross-Electron microscopy of herpes virus. Plate 5 
Journal of General Microbiology, Vol. 19, No. 2

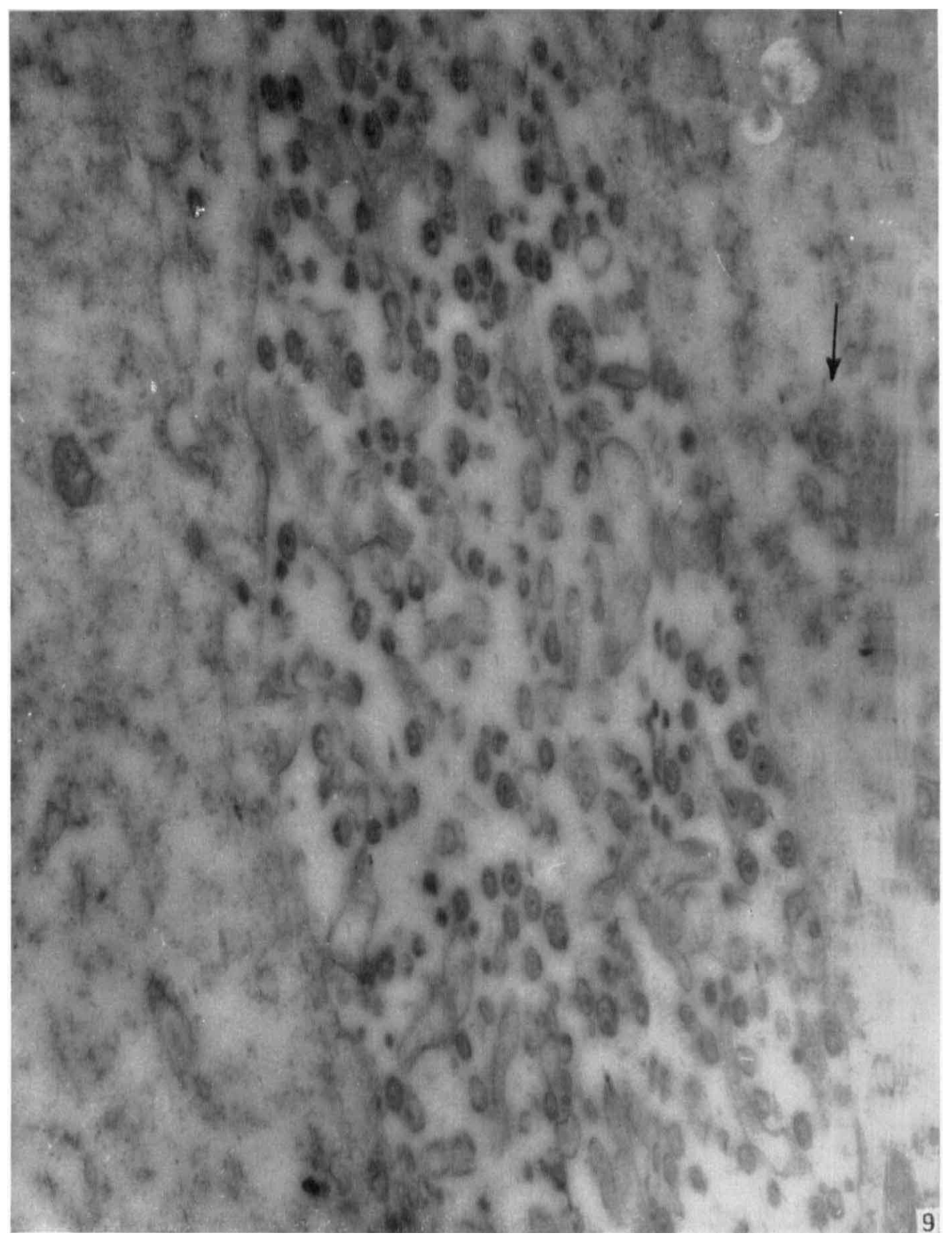

M. G. P. Stoker, K. M. Smith \& R. W. Ross-Electron microscopy of herpes virus. Plate 6 


\section{Journal of General Microbiology, Vol. 19, No. 2}

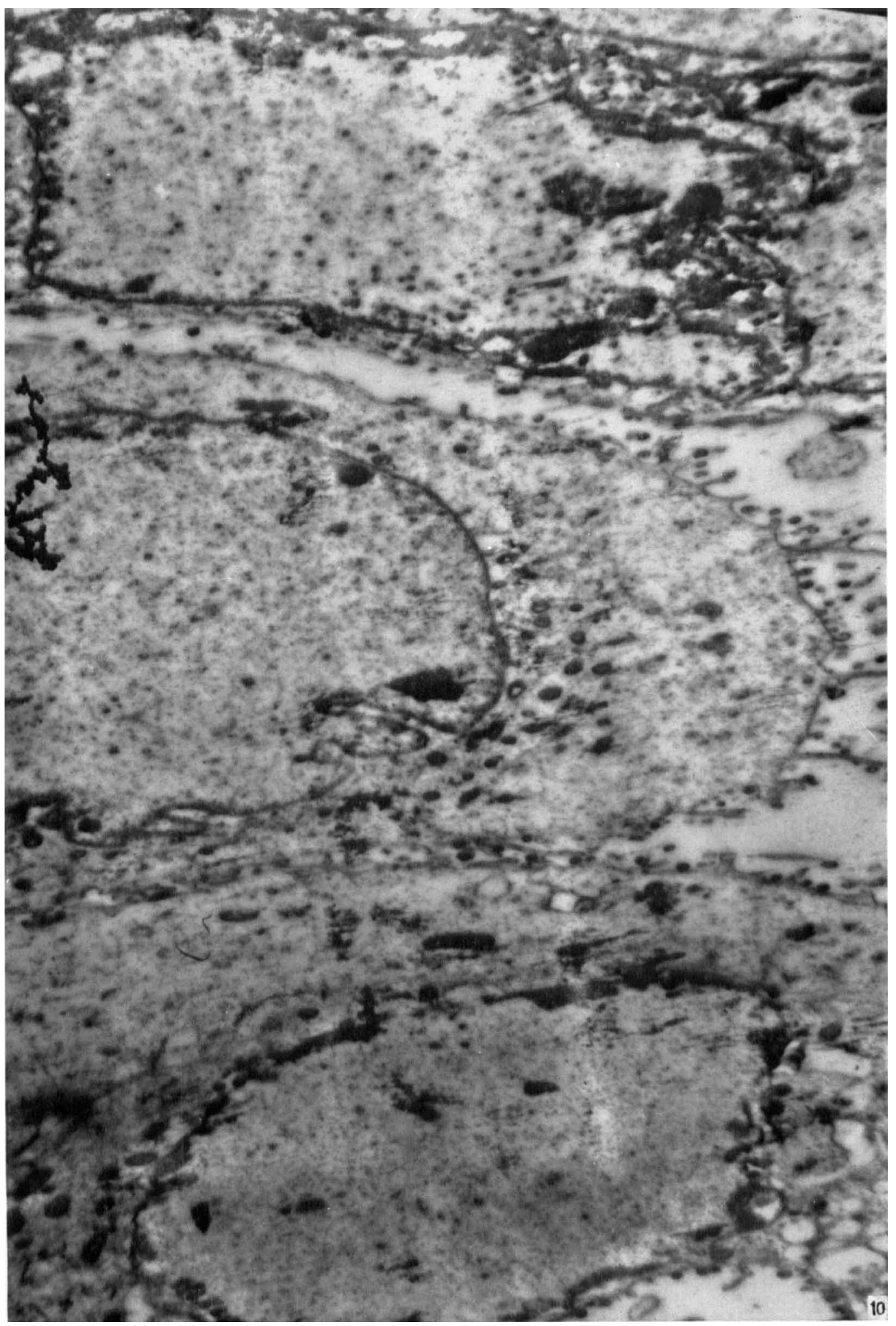

M. G. P. Stoker, K. M. Smith \& R. W. Ross-Electron microscopy of herpes virus. Prate 7 

Plate 6

Fig. 9. $96 \mathrm{hr}$. after infection. Space between two cells packed with characteristic particles. Particles in cell on right appear to be in invaginations of cell membrane. $\times \mathbf{3 2 , 4 0 0}$.

\section{Plate 7}

Fig. 10. $96 \mathrm{hr}$. after infection. Lower magnification of three cells, showing nuclei with marginated chromatin, containing characteristic particles, and many more particles on the surfaces of the cells. $\times 12,000$.

(Received 12 March 1958) 